\title{
DOES THE DEBTOR HAVE TO BE BANKRUPT? - OPPORTUNITIES AND TRENDS PROCEEDINGS OF INSOLVENT ENTREPRENEURS IN POLAND
}

\author{
Anna OLKIEWICZ ${ }^{1}$, Marcin OLKIEWICZ ${ }^{2 *}$ \\ ${ }^{1}$ Koszalin University of Technology, Faculty of Economic Sciences; anna.olkiewicz@tu.koszalin.pl, \\ ORCID: 0000-0002-0142-4548 \\ ${ }^{2}$ Koszalin University of Technology, Faculty of Economic Sciences; marcin.olkiewicz@tu.koszalin.pl, \\ ORCID: 0000-0001-6181-6829 \\ * Correspondence author
}

Purpose: The publication's purpose is to show how bankruptcy and restructuring of entrepreneurs as an instrument protecting the creditor in the event of the contractor's insolvency. The article shows how changing the law affects an organisation's ability to operate with variable risk.

Design/methodology/approach: The conducted research used an analysis of: domestic and foreign literature, given insolvency and restructuring proceedings, as well as changes in law. As part of the conducted works, the following research hypotheses were raised: H1. implementation of legal changes increased the possibilities of functioning and the development of insolvent entities on the market; $\mathrm{H} 2$. interest in restructuring proceedings is increasing, which increases the possibility of recovery for creditors.

Findings: The study showed a trend of increasing amounts of restructuring proceedings. As a result, the number of bankruptcies is reduced, as debtors have more time to prepare arrangement proposals for creditors and convince them of the advantages of the arrangement.

Originality/value: The content of the study confirms the impact of risk and changes in law on increasing the ability to protect organisations from bankruptcy. The paper is dedicated to people dealing with organisation management and the insolvent entrepreneurs and organisations.

Keywords: Entrepreneur, risk, bankruptcy, restructuring proceedings.

Category of the paper: Research paper.

\section{Introduction}

The conduct of business is related to risk. This risk depends, to a large extent, in addition to other factors, on the financial condition and activities of a company's counterparties. It is therefore important to examine which legal instruments can minimise the risk of 
a counterparty. One such instrument is legal proceedings governing the insolvency of a trader. These proceedings, conducted under the supervision of a court, are intended to safeguard the interests of creditors and, in certain situations, to restructure a company at risk of bankruptcy. Therefore, it is important for every entrepreneur to know the opportunities and risks and the rights and obligations of the parties to insolvency and restructuring proceedings.

\subsection{Changes in Polish law}

In recent years, the economic and legal area related to the functioning of entrepreneurs in Poland has been constantly changing. These changes result from the needs and expectations of business operators, their contractors and customers, the immediate and further business environment, the regulations introduced in European Union law, progress, increasing public awareness and, recently, the epidemic threat (Burnes, 2004; Jaki et. al, 2011; Blatz et al., 2006). Therefore, entrepreneurs have to constantly monitor the rights they are entitled to and the obligations that are being imposed upon them. The scale of the problem and changes in law are presented in Table 1.

\section{Table 1.}

The volume of the legal acts published in the Journal of Laws of the Republic of Poland

\begin{tabular}{|c|c|c|c|c|c|c|c|}
\hline Category/Year & $\mathbf{2 0 1 4}$ & $\mathbf{2 0 1 5}$ & $\mathbf{2 0 1 6}$ & $\mathbf{2 0 1 7}$ & $\mathbf{2 0 1 8}$ & $\mathbf{2 0 1 9}$ & $\begin{array}{c}\text { 2020 (until } \\
\text { 2 May 2020) }\end{array}$ \\
\hline $\begin{array}{l}\text { The volume of the legal acts } \\
\text { published in the Journal of Laws } \\
\text { of the Republic of Poland }\end{array}$ & 1995 & 2372 & 2306 & 2509 & 2548 & 2566 & 792 \\
\hline
\end{tabular}

Adapted from: www.dziennikustaw.gov.pl.

Insolvency and restructuring laws are one of the most important laws regulating the functioning of entrepreneurs (Borowiecki and Jaki, 2014; Rojek, 2016; Borowiecki, 2014; Chenhall and Langfield-Smith, 2007, Kücher et al., 2015; Malačič and Malačič, 2016, Pretorius, 2009). These have been changed many times in recent years. Initially, the issues of winding up firms were regulated by two legal acts of 1934, i.e. the regulations established by the President of the Republic of Poland on the Insolvency law and on the arrangement procedures. These acts were repealed on 1 October 2003 by the Bankruptcy and Rehabilitation Acts, which were in force until the end of 2015. However, on 1 January 2016, they were replaced by two other acts that remain in power, i.e. the Insolvency Act and the Restructuring Act.

These acts clearly separate the liquidation of an entrepreneur through bankruptcy from the continuation of his economic activity regulated by the provisions of the restructuring law. (Altman et al., 2017). The choice of the approach depends on the entrepreneur himself, his creditors and the court. However, the premise of each of the procedures is the insolvency or the risk of insolvency of an entrepreneur (Borowiecki and Wysłocka, 2012; Koenner, 2006; Filipiak and Hrycaj, 2017; Gurgul, 2017). 


\subsection{Basic objectives and the business activity of an entrepreneur}

The term entrepreneur has had many definitions in literature and legal regulations. In accordance with the Entrepreneurs Rights dated 6 March 2018, an entrepreneur is defined as a natural or legal person, a body corporate and body incorporated, which is given legal capability by a separate act, who carries on a business ${ }^{1}$. Economic activity, on the other hand, is an organised gainful activity carried out on one's own behalf in a continuous manner. Based on the cited definition, one of the basic features of an entrepreneur is the profitability of his activities. Therefore, the definition proposed by the Polish legislation coincides with the definitions presented in economic literature (Bourne, 2016; Butler, 2011). It follows that even in legal terms, one of the primary aims of an entrepreneur is profitability, which is understood as the ability to generate profits, i.e. to achieve a surplus of revenues over operating costs (Jalilvand and Mallaris, 2012).

Building on the experience of highly developed countries, it can be stated that no better mechanism to bring about economic efficiency has been found so far than the market-based mechanism and being self-employed. Entrepreneurs are the initiators of business developments who are able to discover, disclose and use potential sources of profit (Olkiewicz, 2018; Olkiewicz and Wolniak, 2018; Wolniak et al., 2019). They see what others do not notice and act on the basis of these observations. They undertake business ventures and multiply profits by:

- launching new products on the market,

- creating new markets (previously non-existing markets),

- discovering and creating customer needs,

- discovering and gaining new resources and wealth,

- searching for, developing and implementing new technologies,

- reorganising new and existing enterprises.

An entrepreneur operating on the market has to make choices and decisions about the future (Olkiewicz et al., 2019; Olkiewicz et al., 2020). This is determined by the objectives he wants to achieve, which, apart from maximising profits, may also include:

- maximising the market share (this objective closely correlates with the maximisation of profits and is therefore used alternatively),

- survival,

- security,

- achieving a "satisfactory profit" - the deficiencies and limitations of the decisionmaking process imply the selection of choices that give a "satisfactory profit",

- maximising accumulation on sales,

- maximising the profit/risk relationship.

\footnotetext{
${ }^{1}$ The Act of 6 March 2018 on the Entrepreneurs Law, Journal of Laws 2019, item 1292.
} 
The two most important objectives of companies operating on commercial terms are profitability (i.e. maximising profit or market share) and risk (i.e. security or survival) (Sierpińska and Jachna, 2018). The objective of the decision-makers who are responsible for the future of an enterprise is to choose an option that minimises the risk for a given profit or maximises the profit for a given risk. In the risk management process, the entrepreneur is forced to pay attention to strategic risks that may lead a business to lose liquidity, and even to insolvency and bankruptcy. As shown in Figure 1, strategic risks may arise from four sources: policy and economy, customers, competition or an internal failure.

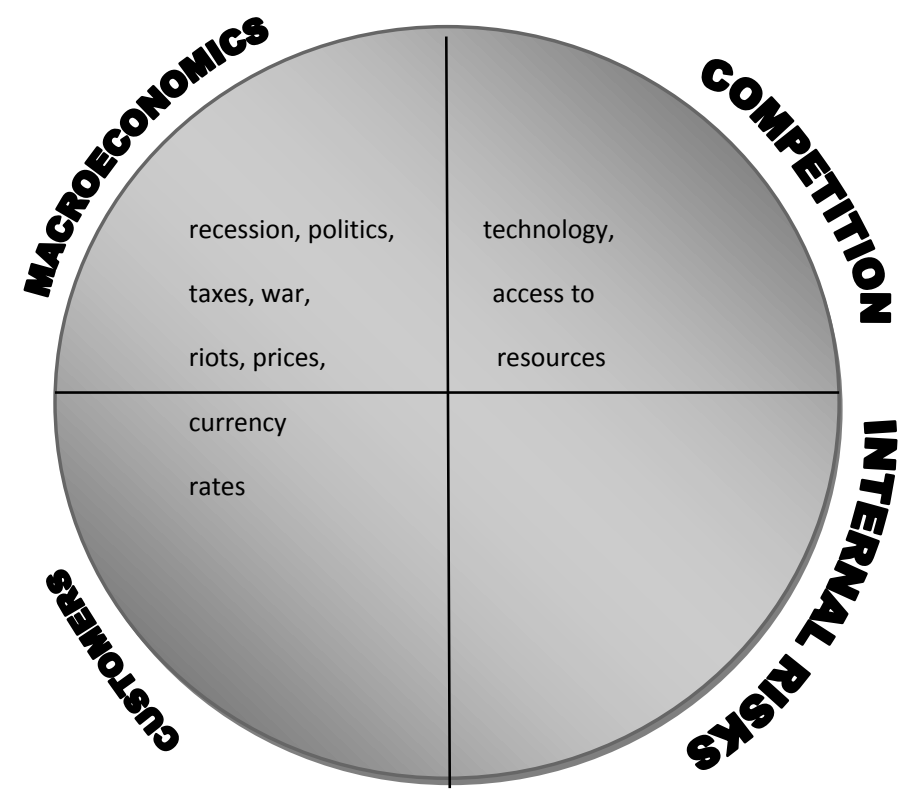

Figure 1. Categories of strategic risks

Adapted from: "The risk mitigation handbook" by K. Sadgrove. Copyright 2017 by Routledge.

The value of an enterprise depends on the value of real cash flows that are connected with its activities. The other important factor determining the value of a company is its competitiveness, understood as a process by which the entrepreneur, in order to achieve his objectives, makes an effort to present offers that are more favourable than others in terms of the price, the quality or other features affecting the decision to enter into a transaction (Marciniak, 2013). The concept of competitiveness can be understood in a different manner by the individual entities cooperating with a given entrepreneur. Figure 2 illustrates the perception of a company's competitiveness by the entities that want to establish business with it. 


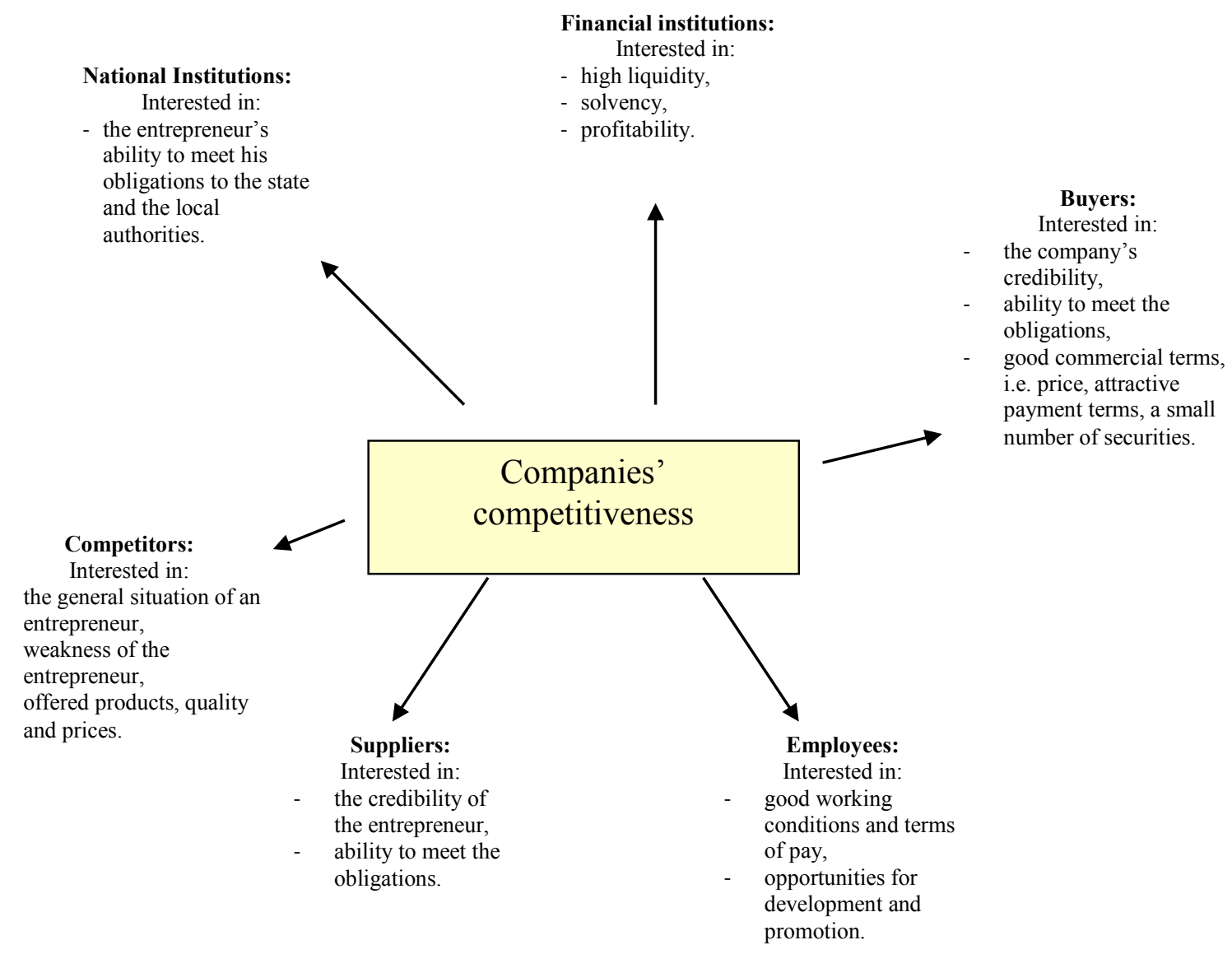

Figure 2. Companies' competitiveness for various operators

Adapted from: "Podstawy prawa dla studentów i praktyków" by A. Olkiewicz. Copyright 2020 by Wydawnictwo Politechniki Koszalińskiej.

An entrepreneur cooperates with various groups of business operators in his environment (buyers, suppliers, financial institutions, state institutions, competitors, employees) (Olkiewicz, 2020a), who assess his competitiveness in different ways. Each of these operators perceives their own economic interest when cooperating with a company. Buyers, for example, will be interested in the best sale conditions. With equal product quality, a buyer will choose the offer of a company that has the most favourable sales conditions, e.g. a longer payment period, the cheapest and least formalised security option. The supplier, on the other hand, will perceive the company as competitive if it ensures the safety of cooperation, e.g. guarantees and secures payment. The warranty for the proper implementation of a contract will be achieved by a company that manages to properly secure their contracts.

In addition, the entrepreneur operates within a certain legal and economic framework and is required to adapt to the generally accepted principles of conducting business. Some of these principles have been developed through business practice and are accepted in terms of good practice. Other principles have been sanctioned in order to force business operators to comply with the rules that serve the common good, consumer interests or to protect competitiveness. 
The main principles under which economic activities operate in Poland are as follows (Olkiewicz, 2020):

- freedom of economic activity and equality among entrepreneurs, according to which engaging, conducting and termination of economic activity is free for everyone on equal footing,

- "everything that is not forbidden by law is allowed", which stipulates that an entrepreneur may undertake all actions except those prohibited by law and may be required to conduct specific behaviour only on the basis of legal rules,

- respect for fair competition, morality and the interests of others, according to which an entrepreneur carries out economic activities based on the principles of fair competition, respect for decency and the legitimate interests of other entrepreneurs and consumers, as well as to respect and protect human rights and freedoms,

- the presumption of an entrepreneur's integrity, based on which the authority is guided in its activities by the principle of trust in the entrepreneur, assuming that he acts in accordance with the law and with fairness and respect for good business practices,

- resolving factual doubts in favour of the entrepreneur,

- legal certainty, which stipulates that the authority shall not depart from the established practice of settling cases in the same factual and legal state without due cause,

- freedom of contract, which is of fundamental significance in business transactions,

- friendly interpretation of the provisions of law, based on which when the judgement of the proceedings imposes an obligation or limits or revokes the rights of the entrepreneur, and there are concerns to the content of the legal norm in the case, these doubts are to be resolved in favour of the entrepreneur,

- the obligation to obtain an entry in the relevant register,

- the obligation to settle payments via a payment account when the value of the transactions exceeds PLN 15,000,

- the obligation to use a Tax Identification Number (NIP),

- the obligation to affix corresponding indications on the products, which means that an entrepreneur that places goods on the market in the territory of the Republic of Poland is obliged to place information written in Polish describing the manufacturer's company name, address, the country in which the producer's head office is established and data that enables identification of the product, unless the purpose of the product is obvious.

The principles listed above define the rights and obligations placed on both the entrepreneurs and public administrative authorities.

The adopted solutions guarantee the principle of economic freedom, while at the same time respecting the interests of consumers and ensuring that entrepreneurs abide by the law. 


\subsection{Risk in the activity of an entrepreneur}

Literature sources provide many definitions of the term risk and presents three main approaches to risk (Gebhard et al., 1993). In terms of effects (Figure 3), risk refers to:

- the possibility of incurring a loss - this approach underlines the negative consequences of the risk and indicates that it should be treated as a threat; in this situation, the term risk means the amount that can be lost as a result of a particular transaction,

- the discrepancy between the revenues obtained and their expected value; in this situation, risk means that the effect will not correspond with the expectations; in some cases, a risk can be an opportunity, and in other cases, a threat (Van Horne and Wachowicz, 2009).

THE LACK OF

STABILITY AND

CERTAINTY OF

ECONOMIC

CONDITIONS

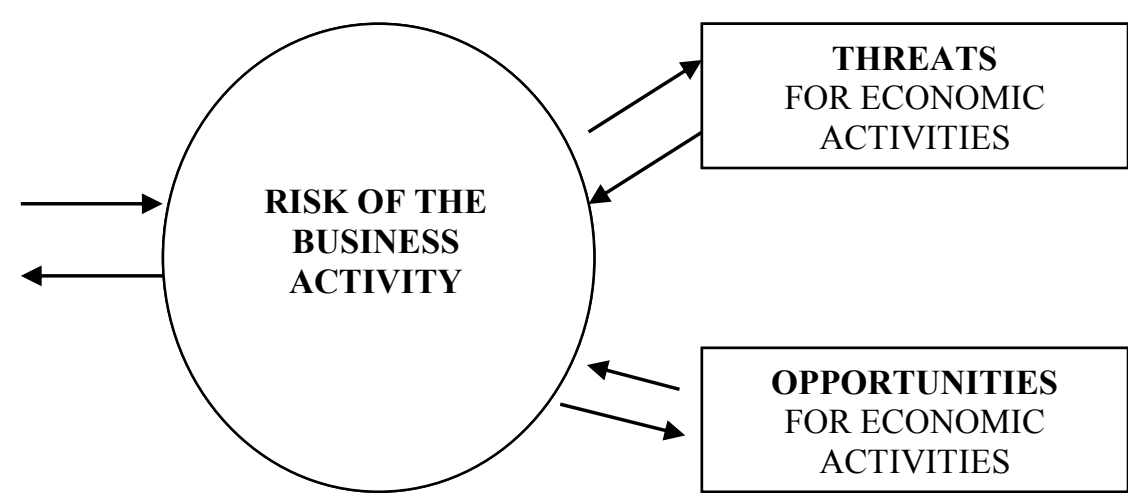

Figure 3. Interrelations between volatility, a business risk, dangers and opportunities

Adapted from: "Podstawy prawa dla studentów i praktyków" by A. Olkiewicz. Copyright 2020 by Wydawnictwo Politechniki Koszalińskiej.

A risk, from the informational point of view concerning the causes of risk occurrence, means that due to incomplete information, decisions are made that are not optimal in terms of achieving objectives (Kreim, 1988; Lukason and Laitinen, 2016).

Due to probabilistic and statistical measures used to measure risk, it is defined by the differentiation of profits that can be achieved from an investment (Olkiewicz, 2019). This may result in a deviation from the planned performance effects. These deviations are subject to the law of large numbers and can be based on probability calculation. Basic statistical measures are used to determine the amount of risk, such as variance and standard deviation (Zeliaś ed., 1998). It is assumed that the larger the deviations, the greater the risk associated with making a specific decision. While equally treating the positive and negative deviations, the occurrence of a negative deviation also means that profits will be lower than anticipated.

A transaction risk is one of the most significant risks that can occur in business activity. It means that the contractor can, for various reasons, fail to comply with the contract. The contractor may therefore commit, in particular, to: a delay in payment, not paying for the goods at all, failing to undertake the execution of a transaction or going bankrupt (Jones, 2010; Dhingra and Aggarwal, 2014; Dong et al., 2006). Each of these situations has negative effects 
on the entrepreneur. In Polish and foreign legislation, there are a number of legal instruments aimed at reducing transaction risks and protecting entrepreneurs. Example of such instruments are regulations regarding the insolvency of entrepreneurs and consumers, which are intended to secure the best interests of the creditors and enable the debtor to function in economic life.

\section{Methods}

The subject of the study is important for both scientists and entrepreneurs. In the era of globalisation and growing risk, companies are struggling with financial difficulties, often becoming insolvent contractors. The insolvency of one entity may result in another insolvency ("snowball" theory), which, in turn, may have an impact on, among others, increasing unemployment, the number of enterprises going bankrupt or the quality of life of the inhabitants of a given region.

The publication's purpose is to show how bankruptcy and restructuring of entrepreneurs as an instrument protecting the creditor in the event of the contractor's insolvency. The following hypotheses were adopted:

- H1: implementation of legal changes increased the possibilities of functioning and the development of insolvent entities on the market,

- H2: interest in restructuring proceedings is increasing, which increases the possibility of recovery for creditors.

The study analyses domestic and foreign literature on the subject and legal acts in the area of managing organisations in difficult economic situations. In particular, the focus was on restructuring and bankruptcy activities, as they are often the result of entrepreneurs taking risks.

\section{Results and discussion}

The regulations concerning the insolvency of an entrepreneur and the principles of meeting his obligations are currently regulated by two legal acts, i.e. the Bankruptcy Law of 28 February 2003 and the Restructuring Act of 15 May 2015. Knowledge of these legal acts is important, because the number of business operators conducting business activities increases annually, and thus the value of their liabilities for various reasons. Table 2 illustrates how the number of entrepreneurs, their legal forms and liabilities have changed in the period from 2010 to 31 March 2020. 
Table 2.

Number of business operators registered in REGON and their liabilities

\begin{tabular}{|c|c|c|c|c|c|c|}
\hline Years & $\mathbf{2 0 1 0}$ & $\mathbf{2 0 1 5}$ & $\mathbf{2 0 1 6}$ & $\mathbf{2 0 1 7}$ & $\mathbf{2 0 1 8}$ & $\mathbf{3 1}$ March 2020 \\
\hline Trade companies & 303,040 & 456,910 & 501,056 & 537,273 & 489,908 & 529,600 \\
\hline $\begin{array}{c}\text { Natural persons performing } \\
\text { business activity }\end{array}$ & $2,942,965$ & $2,972,144$ & $2,968,786$ & $3,001,353$ & $3,111,733$ & $3,227,836$ \\
\hline Cooperatives & 17,156 & 17,561 & 17,633 & 17,694 & 11,655 & 11,414 \\
\hline Others & 646,641 & 737,794 & 750,216 & 753,480 & 752,079 & 766,058 \\
\hline $\begin{array}{c}\text { The number of business } \\
\text { operators conducting } \\
\text { business activity in Poland } \\
\text { registered in REGON }\end{array}$ & $3,909,802$ & $4,184,409$ & $4,237,691$ & $4,309,800$ & $4,365,375$ & $4,534,908$ \\
\hline $\begin{array}{c}\text { The liabilities of } \\
\text { entrepreneurs stated } \\
\text { in PLN millions }\end{array}$ & 869,490 & $1,184,974$ & $1,291,366$ & $1,350,446$ & $1,436,808$ & Lack of data \\
\hline
\end{tabular}

Adapted from: Statistical Yearbook of the Republic of Poland 2018, GUS 2019; Statistical Yearbook of the Republic of Poland 2019, GUS 2020.

The data in the table indicates that the number of entrepreneurs in the analysed period was constantly increasing. This increase amounted to $25 \%$. The debt of business operators registered in REGON also grew systematically. From 2010 to 2018 , the debt amounted to $65 \%$. It can be stated that legislation, by introducing new regulations concerning bankruptcy and restructuring, has consciously reacted to the changes happening in the economy. The increase in entrepreneurs' debt increases the risk of business activity and may lead to insolvency, which in turn may affect the contractors of the insolvent entities.

The existing regulations, in force since 1 January 2016, generally introduced two proceedings for the insolvent entrepreneurs, i.e. the possibility of liquidation through bankruptcy proceedings and the possibility of helping a business survive through restructuring. Currently, both proceedings can be used by entrepreneurs that became insolvent. Business operators threated with insolvency may, on the other hand, use one of the restructuring proceedings.

Pursuant to the regulations of the Bankruptcy Act, an insolvent entrepreneur is a debtor who has lost the capability to perform his maturing liabilities. The Act introduces a presumption that the debtor has lost his ability to perform his maturing liabilities if the delay in performing his obligations exceeds a period of three months. In addition, the Act further clarifies that in the case of legal persons or organisational units without legal personality, to whom a separate law grants a legal capacity, an insolvent entrepreneur is a debtor when his pecuniary obligations exceed the value of his assets and such a situation has lasted for more than twenty-four months ${ }^{2}$.

The Restructuring Law also specifies that an entrepreneur that is at risk of insolvency is one whose economic situation indicates that he might go bankrupt ${ }^{3}$. The primary objective of insolvency proceedings is to satisfy the creditors as much as possible, while at the same time, if rational conditions allow, maintaining the debtor's enterprise. The purpose of restructuring

\footnotetext{
2 The Act dated 28 February 2003 on the bankruptcy law, Journals of Laws 2019, item 498.

${ }^{3}$ The Act dated 15 May 2015 on the restructuring law, Journal of Laws 2019, item 243, article 6.
} 
proceedings, on the other hand, is to not allow the debtor to go bankrupt by restructuring his assets through an arrangement with his creditors, and in the case of remedial proceedings, carrying out remedial measures while securing the legitimate rights of the creditors. Legislation has indicated that this objective, in the course of proceedings, is to be achieved by allowing the debtor to restructure his assets through an arrangement with his creditors. The objective of the sanative proceedings may additionally be achieved by carrying out sanctioning activities while securing the legitimate rights of the creditors (Filipiak and Hrycaj, 2019).

Table 3 presents legal possibilities that entrepreneurs may take in the case of losing the capability to settle payable liabilities or when there is a risk of such difficulties occurring.

Table 3.

Types and objectives of proceedings concerning insolvent entrepreneurs

\begin{tabular}{|c|c|}
\hline Types of proceedings & $\begin{array}{l}\text { The objectives of the proceedings } \\
\end{array}$ \\
\hline $\begin{array}{l}\text { Bankruptcy can be used by } \\
\text { entrepreneurs that have become } \\
\text { insolvent }\end{array}$ & $\begin{array}{l}\text { Proceedings should be conducted in such a manner that the claims of the } \\
\text { creditors can be satisfied as much as possible, while at the same time, } \\
\text { if rational conditions allow it, maintaining the debtor's enterprise. }\end{array}$ \\
\hline \multirow[b]{2}{*}{$\begin{array}{l}\text { Restructuring proceedings can } \\
\text { be used by insolvent or } \\
\text { financially distressed debtors, } \\
\text { within the framework of which } \\
\text { the following proceedings may } \\
\text { be conducted: }\end{array}$} & Main objective \\
\hline & $\begin{array}{l}\text { To avoid the debtor from going bankrupt by: } \\
-\quad \text { allowing the debtor to restructure his assets through an arrangement } \\
\text { with his creditors, } \\
\text { - in the case of sanitation proceedings - by carrying out sanitation } \\
\text { proceedings while securing the legitimate rights of the creditors. }\end{array}$ \\
\hline $\begin{array}{l}\text { 1. Proceedings for the } \\
\text { approval of an agreement }\end{array}$ & $\begin{array}{l}\text { - allows one to conclude the out-of-court approval of an agreement by } \\
\text { collecting the creditors' votes individually by the debtor, } \\
\text { may be conducted if the sum of disputed claims entitling one to vote } \\
\text { on the arrangement does not exceed } 15 \% \text { of the sum of claims entitling } \\
\text { one to vote on the arrangement. }\end{array}$ \\
\hline $\begin{array}{l}\text { 2. Accelerated arrangement } \\
\text { proceedings }\end{array}$ & $\begin{array}{l}\text { - allows the debtor to enter into an arrangement after the preparation and } \\
\text { approval of the list of claims in a simplified form, } \\
\text { may be conducted if the sum of the disputed claims entitling one to vote } \\
\text { on the arrangement does not exceed } 15 \% \text { of the sum of claims entitling } \\
\text { one to vote on the arrangement. }\end{array}$ \\
\hline 3. Composition proceedings & $\begin{array}{l}\text { - allows the debtor to enter into an arrangement after the preparation and } \\
\text { approval of the list of claims, } \\
\text { - may be conducted if the sum of the disputed claims entitling one to vote } \\
\text { on the arrangement does not exceed } 15 \% \text { of the sum of claims entitling } \\
\text { one to vote on the arrangement. }\end{array}$ \\
\hline 4. Remedial proceedings & $\begin{array}{l}\text { - allows the debtor to carry out remedial activities and conclude an } \\
\text { arrangement after drafting and approving the claims. } \\
\text { Remedial activities are legal and factual activities that aim to improve the } \\
\text { economic situation of the debtor and restore the debtor's capability to } \\
\text { perform his obligations, while protecting him from financial enforcement. }\end{array}$ \\
\hline
\end{tabular}

Adapted from: own study based on the Acts on the bankruptcy and restructuring laws.

Table 3 shows that entrepreneurs who are currently at risk of insolvency or that are insolvent have many options to choose from regarding whether to continue their business operation or to close it down. In theory, each of the proceedings is aimed at protecting the legal and financial situation of the creditors. However, the effects of carrying out proceedings can prove to be detrimental to them. The purpose of bankruptcy proceedings is to liquidate the entrepreneur, but the law makes it possible to change the proceedings during the course of restructuring, 
provided that an arrangement concerning the repayment of liabilities with the creditors is concluded if this were to lead to better protection of the interests of the creditors. The main objective of the restructuring proceedings, on the other hand, is to avoid the bankruptcy of the debtor. However, if, in the course of the proceedings, this proves to be impossible, the proceedings can change into insolvency proceedings. It would therefore appear that the modes provided for in the Restructuring Law and Insolvency Law provide better opportunities for debtors than in the former regulations.

It is worth adding that the commencing of both restructuring and insolvency proceedings has profound implications for creditors. These implications are presented in Table 4.

Table 4.

Consequences of commencing insolvency and restructuring proceedings

\begin{tabular}{|c|c|}
\hline $\begin{array}{c}\text { Consequences of commencing insolvency } \\
\text { proceedings } \\
\end{array}$ & $\begin{array}{c}\text { Consequences of commencing restructuring } \\
\text { proceedings }\end{array}$ \\
\hline $\begin{array}{l}\text { 1. The assets of the insolvent person become } \\
\text { bankruptcy estate. } \\
\text { 2. The bankruptcy estate is taken over by a trustee } \\
\text { who, under the supervision of the judge- } \\
\text { commissionaire, will liquidate it. } \\
\text { 3. The trustee makes an inventory of the assets and } \\
\text { drafts a list of claims which will form the basis for } \\
\text { any potential repayments. } \\
\text { 4. Creditors are satisfied in the following order: } \\
\text { a) } \mathbf{1}^{\text {st }}-\text { covers, for example, liabilities for the } \\
\text { time prior to bankruptcy, liabilities related to } \\
\text { employment contracts, maintenance claims, } \\
\text { liabilities resulting from the restructuring } \\
\text { proceedings, } \\
\text { b) } \mathbf{2}^{\text {nd }}-\text { other liabilities, if they are not satisfied } \\
\text { in other categories, } \\
\text { c) } \mathbf{3}^{\text {rd }}-\text { interest on receivables falling under } \\
\text { higher categories in the order in which capital } \\
\text { is to be satisfied, as well as judicial and } \\
\text { administrative penalties and receivables } \\
\text { under donations and bequests, } \\
\text { d) } \mathbf{4}^{\text {th }}-\text { receivables of the business partners or } \\
\text { shareholders on loans made to the insolvent } \\
\text { person who has the status of a capital } \\
\text { company in the period of five years prior to } \\
\text { bankruptcy, including interest. }\end{array}$ & $\begin{array}{l}\text { 1. The execution proceedings are suspended by the } \\
\text { operation of law concerning claims that are, by } \\
\text { the operation of law, included with an } \\
\text { arrangement, excluding the following claims: } \\
\text { *maintenance, *compensation pensions, *social } \\
\text { security pensions, *from employment } \\
\text { relationship, *secured on the debtor's asset with a } \\
\text { mortgage, pledge and other property rights. } \\
\text { The entrepreneur's assets are left to the } \\
\text { management board under the supervision of a } \\
\text { supervisor, or the they are taken by the supervisor. } \\
\text { The debtor drafts arrangement proposals, which } \\
\text { usually include: *reduction of liabilities, } \\
\text { *dividing them into instalments, *reduction of } \\
\text { interest, *restructuring of the debtor's assets. } \\
\text { Arrangement proposals may provide for the } \\
\text { division of creditors into groups covering specific } \\
\text { categories of interests. } \\
\text { The conditions for restructuring the debtor's } \\
\text { obligations are the same for all creditors, and if } \\
\text { the voting on an arrangement is carried out in } \\
\text { groups of creditors, they will be the same for the } \\
\text { creditors in the same group, unless a creditor } \\
\text { agrees to less favourable conditions. } \\
\text { The arrangement binds creditors whose claims } \\
\text { are, under the act, included in the arrangement, } \\
\text { even if they were not included in the list of claims. } \\
\text { The act of the creditors' meeting to approve the } \\
\text { arrangement is adopted if the majority of the } \\
\text { voting creditors who cast a valid vote will be in } \\
\text { favour of the act, while having at least two-thirds } \\
\text { of the total amount of liabilities among the } \\
\text { creditors who are entitled to vote. }\end{array}$ \\
\hline
\end{tabular}

Adapted from: own study based on the Acts on the bankruptcy and restructuring laws.

Table 4 shows that the initiation of bankruptcy or restructuring proceedings can halt the execution of the debtor's property. Even those creditors who have successfully carried out such an execution previously have to take into consideration other creditors and the decisions of the 
trustee, the supervisor or the administrator. The creditors are treated in the same way during these proceedings. Only those creditors who have a claim on the debtor's property are in a favourable position, as they can recover the amount specified in the collateral from this collateral subject.

Based on the number of bankruptcy and restructuring proceedings initiated and conducted in recent years (Figure 4), it can be stated that they are especially appreciated by the debtors. Although the number of bankruptcies has been decreasing over the last five years, there is a growing trend and a strong interest from entrepreneurs in restructuring proceedings introduced by legislation. The number of these proceedings has been increasing for the past two years.

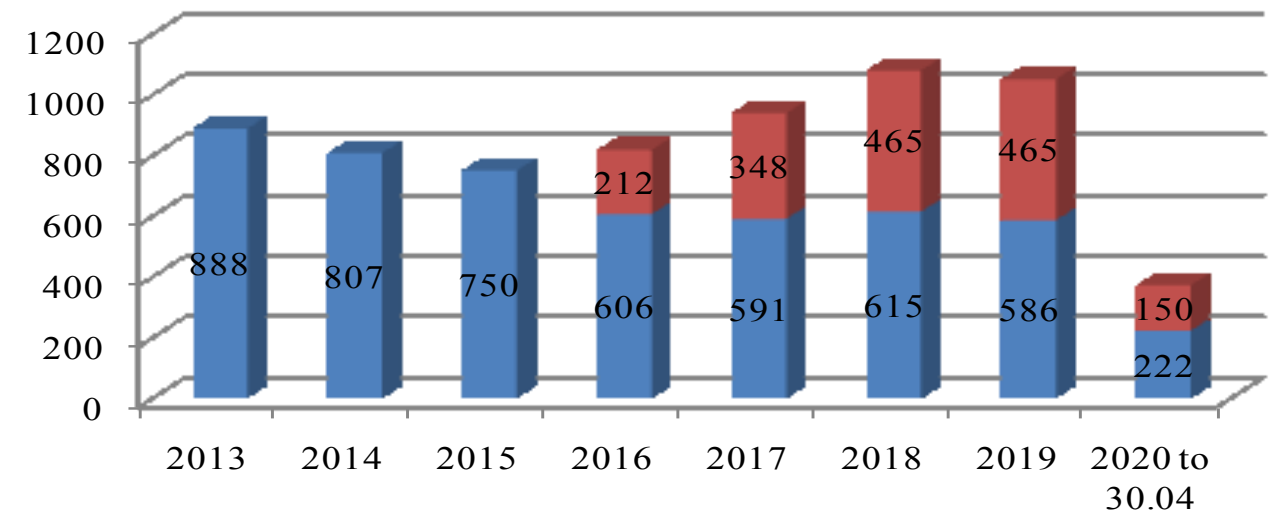

The number of bankruptcies in Poland $\square$ The number of restructuring in Poland

Figure 4. The number of bankruptcy and restructuring proceedings in Poland in 2013-2019. Adapted from: own study based on the data from Monitor Sądowy i Gospodarczy 2019, 2020.

The presented statement clearly shows that entrepreneurs are gradually becoming more and more interested in restructuring proceedings. These proceedings have a strong advantage, i.e. they halt the execution that occurs by the operation of law upon the issuance of a decision to initiate such proceedings. Thus, from the time the proceedings are initiated, debtors have time to prepare arrangement proposals for the creditors and convince them about the advantages of the arrangement. From the point of view of the national economy and the interests of debtors, restructuring of a company has more advantages than bankruptcy (Malačič and Malačič, 2016; Henderson, 1999; Thornhill and Amit, 2003; Cochran, 1981; Pretorius, 2009). This usually means that jobs will be preserved, the business will continue to function and part of the debt and liabilities will be reduced. Restructuring, however, means that creditors have to agree to a partial reduction of their claims. The debtor usually proposes to write off the incidental costs and a part of the main debt and asks for the deferment of payment or payment of the debt in instalments. This arrangement is carried out after it is effectively concluded and approved by the court. In case the arrangement is not implemented, the proceedings may end in bankruptcy. 


\section{Summary}

Studies have shown that in recent years, regulations on the insolvency of entrepreneurs in Poland have changed significantly. The changes in law introduced the possibility of restructuring even an insolvent company. The aim of the changes is to protect creditors as best as possible, while, if possible, sanitation the debtor's activities. Such regulations have a positive impact on market confidence and the labour market. Research has also shown that the solutions introduced are increasingly popular with entrepreneurs who are more likely to decide on restructuring than filing for bankruptcy.

\section{References}

1. Altman, E.I., Iwanicz-Drozdowska, M., Laitinen, E.K., and Suvas, A. (2017). Financial distress prediction in an international context: a review and empirical analysis of Altman's Z-Score model. Journal of International Financial Management and Accounting, Vol. 28, No. 2, pp. 131-171. doi.org/10.1111/jifm.12053.

2. Blatz, M., Kraus, K.J., Haghani, S. (2006). Corporate Restructuring: Finance in Times of Crisis. Berlin: Springer - Verlag.

3. Borowiecki, R. (2014). Zarzadzanie restrukturyzacja przedsiębiorstw i gospodarki. Uwarunkowania - procesy - efekty. Kraków: Wyd. UEK - Fundacja UEK.

4. Borowiecki, R., Jaki, A. (2014). Restrukturyzacja w obliczu wyzwań gospodarki globalnej. Kraków: Wyd. UEK - Fundacja UEK.

5. Borowiecki, R., Wysłocka, E. (2012). Analiza ekonomiczna i ocean ekspercka w procesie restrukturyzacji przedsiębiorstw. Warszawa: Difin.

6. Bourne, N. (2016). Bourne on comapany Law. London: Routledge.

7. Burnes,. B. (2004). Managing Change: A Strategic Approach to Organizational Dynamics. 4th Ed. Harlow, Essex: Prentice Hall.

8. Butler, D. (2011). Business development, A guide to small business strategy. London: Routledge.

9. Chenhall, R.H., Langfield-Smith, K. (2007). Multiple perspectives of performance measures. European Management Journal, vol. 25, no.4, pp. 266-282.

10. Cochran, A.B. (1981). Small business mortality rates: a review of the literature. Journal of Small Business Management, Vol. 19, No. 4, pp. 50-59.

11. Dhingra, D., Aggarwal, N. (2014). Corporate Restructuring in India: A Case Study of Reliance Industries Limited (RIL). Global Journal of Finance and Management, Vol. 6, no. 9, pp. 813-820. 
12. Dong, X.Y., Putterman, L., Unel, B. (2006). Enterprise restructuring and firm performance: a comparison of rural and urban enterprises in Jiangsu province. Journal of Comparative Economics, Vol. 34, no 3, pp. 608-633. doi:10.1016/j.jce.2006.06.005.

13. Filipiak, P., Hrycaj, A. (2017). Prawo restrukturyzacyjne. Komentarz. Warszawa: Wolters Kluwer.

14. Filipiak, P., Hrycaj, A. (2019). Prawo restrukturyzacyjne. Komentarz. Warszawa: Wolters Kluwer.

15. Gebhard, G., Gerke, W., Steiner, M. (1993). Grundlagen des finanzwirtschaftlich Orientieren Risikomanagement. München: C.H. Beck'sche Verlagsbuchhandlung.

16. Gurgul, S. (2017). Prawo upadtościowe. Prawo restrukturyzacyjne. Komentarz. Warszawa: C.H. BECK.

17. Henderson, A.D. (1999). Firm strategy and age dependence: a contingent view of the liability of newness, adolescence and obsolescence. Administrative Science Quarterly, Vol. 44, No. 2, pp. 281-314.

18. Jaki, A., Kaczmarek, J., Rojek,T. (2011). Restrukturyzacja. Teoria i praktyka w obliczu nowych wyzwań. Kraków: Wyd. UEK - Fundacja UEK.

19. Jalilvand, A., Malliaris, A.G. (2012). Risk management and corporate governance. New York: Taylor \& Francis.

20. Jones, G. (2010). Organizational Theory, Design and Change. New Jersey: Pearson Prentice Hall.

21. Koenner, M. (2006), Likwidacja upadłościowa. Kraków: Zakamycze.

22. Kreim, E. (1988). Zukunftsorientiere Kreditenscheidung. Wiesbaden: Springer.

23. Kücher, A., Feldbauer-Durstmüller, A., Duller, C. (2015). The intellectual foundations of business failure - a co-citation analysis. Journal of International Business and Economics, Vol. 15, No 2, pp.13-38.

24. Lukason, O., Laitinen, E.K. (2016). Failure processes of old manufacturing firms in different european countries. Investment Management and Financial Innovations, Vol. 13, No. 2, pp. 310-321. doi: 10.21511/imfi.13(2-2).2016.06.

25. Malačič, N., Malačič, I. (2016). Key factors for successful financial and business restructuring with a general corporate restructuring model and Slovenian companies. Case studies. Ljubljana: Institute for Economic Research.

26. Marciniak, S. (2013). Makro i mikroekonomia. Podstawowe problemy wspótczesności. Warszawa: PWN.

27. Olkiewicz, A. (2020). Podstawy prawa dla studentów i praktyków. Koszalin: Wydawnictwo Politechniki Koszalińskiej.

28. Olkiewicz, A., Wolniak, R., Olkiewicz M., Szymczewska, M. (2020). The Impact of Professional and Economic Activity on the Development of Apartments' Market. European Research Studies Journal, Vol. XXIII, Iss. 1, pp. 404-418. doi: 10.35808/ersj/1558. 
29. Olkiewicz, M. (2018). Quality improvement through foresight methodology as a direction to increase the effectiveness of an organization. Contemporary Economics, 12(1), 69-80. doi:10.5709/ce.1897-9254.264.

30. Olkiewicz, M. (2019). Foresight as a shaping instrument of innovation, Scientific Papers of Silesian University of Technology Organization and Management Series, No. 13, pp.107119. doi: 10.29119/1641-3466.2019.133.9.

31. Olkiewicz, M. (2020). The role of the stakeholder in the quality improvement of an organization, S Scientific Papers of Silesian University of Technology Organization and Management Series, No. 143, p. 235-245; doi.org/10.29119/1641-3466.2020.143.19.

32. Olkiewicz, M., Wolniak, R. (2018). The impact of natural environment on food safety. Rocznik Ochrona Środowiska, 20, 804-818.

33. Olkiewicz, M., Wolniak, R., Eva-Grebski, M., Olkiewicz, A. (2019). A Comparative Analysis of the Impact of the Business Incubator Center on the Economic Sustainable Development of the Region in USA and Poland, Sustainability, 11(1), 173, doi: org/10.3390/su11010173.

34. Pretorius, M. (2009). Defining business decline, failure and turnaround: a content analysis. Southern African Journal of Entrepreneurship and Small Business Management, Vol. 2, No. 1, pp. 1-16. doi.org/10.4102/sajesbm.v2i1.15.

35. Rocznik statystyczny Przemystu 2017 (2018). Warszawa: Wyd. GUS.

36. Rocznik Statystyczny Rzeczpospolitej Polskiej 2017. (2018). Warszawa: Wyd. GUS,.

37. Rojek, T. (2016). Wykorzystanie narzędzi restrukturyzacji w procesie zarządzania efektywnością przedsiębiorstwa. Studia Oeconomica Posnaniensia, vol. 4, no. 2, pp. 135154. doi: 10.18559/SOEP.2016.2.7.

38. Sadgrove, K. (2017). The risk mitigation handbook. Practical steps for reducing your business risks. New York: Routledge.

39. Sierpińska, M., Jachna, T. (2018). Ocena przedsiębiorstwa wedtug standardów światowych. Warszawa: PWN.

40. Thornhill, S., Amit, R. (2003). Learning about failure: bankruptcy, firm age, and the resource-based view. Organization Science, Vol. 14, No. 5, pp. 497-509. Doi: 10477039/03/1405/0497.

41. Ustawa z dnia 28 lutego 2003 r. Prawo upadłościowe, Dz.U. z 2019r. poz. 498, t.j.

42. Ustawa z dnia 6 marca 2018 r. Prawo przedsiębiorców, Dz.U. z 2018r. poz. 646.

43. Ustawa z dnia z dnia 15 maja 2015 r. Prawo restrukturyzacyjne, Dz.U. z 2019 poz.243 t.j.

44. Van Horne, J.C., Wachowicz, J.M. (2009). Fundamentals of financial management. Englewood Cliffs: Prentice Hall.

45. Wolniak, R., Grebski, M.E., Skotnicka-Zasadzień, B. (2019). Comparative analysis of the level of satisfaction with the services received at the business incubators. Sustainability, 10(2889), 1-22. doi.org/10.3390/su11102889.

46. Zeliaś, A. (1998). Statystyczne metody oceny ryzyka w działalności gospodarczej. Kraków: Wyd. Akademii Ekonomicznej. 